Available online on 15.03.2019 at http://ujpr.org
Universal Journal of Pharmaceutical Research
An International Peer Reviewed Journal
Open access to Pharmaceutical research
Commercial Share Alike 4.0 License which permits unrestricted non commercial use,
provided the original work is properly cited
Volume 4, Issue 1, 2019

\title{
HEPATOPROTECTIVE ACTIVITY OF ASPARAGUS RACEMOSUS ROOT EXTRACT ON LIPOPOLYSACCHARIDE INDUCED OXIDATIVE STRESS IN RATS
}

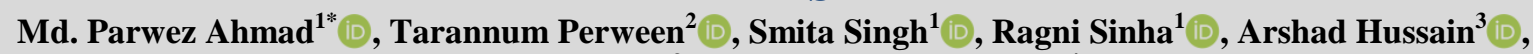
Shadma Wahab ${ }^{3}$, Awadhesh Kumar Jha $^{4}(\mathbb{D})$

${ }^{I}$ Department of Pharmacology, National Medical College Teaching Hospital, Birgunj, Nepal.

${ }^{2}$ Department of Obstetrics and Gynaecology, Rahmania Medical Centre, Motihari, Bihar, India.

${ }^{3}$ Faculty of Pharmacy, King Khalid University, Kingdom of Saudi Arabia (KSA).

${ }^{4}$ Department of Pharmacology, Government Medical College, Bettiah, India.

\section{ABSTRACT}

Objective: Lipopolysaccharide (endotoxin) produces an inflammatory condition leading to multiple organ failure. LPS most potent bacterial products are used for induction of host oxidative stress responses and liver injury.

Methods: Present study was undertaken to investigate the effect of Asparagus racemosus Willd. root extract in lipopolysaccharide (LPS) induced oxidative stress in rats by measuring oxidative stress markers, nitric oxide, liver function test and cytokines.

Results: The obtained data showed that LPS administration significantly reduced glutathione (GSH), superoxide dismutase (SOD) and catalase (CAT), total cholesterol (TC) and albumin (ALB). There was significant increase in malondialdehyde (MDA), cytokines activity, serum aspartate transaminase(AST), alanine transaminase(ALT), alkaline phosphate (ALP), total bilirubin (TB) and nitric oxide(NO).

Conclusion: The methanolic extract of Asparagus racemosus (MEAR) administration significantly $(P<0.05)$ reduced LPSinduced oxidative stress by normalizing liver GSH, SOD, CAT, MDA, NO, cytokines and liver function markers. MEAR significantly increased ALB and TC level. Results suggest that MEAR protects the liver against liver toxicity induced by LPS.

Keywords: Asparagus racemosus, cytokine, hepatoprotective, lipopolysaccharide, oxidative stress, quercetin.

Article Info: Received 1 January 2019; Revised 3 February; Accepted 5 March, Available online 15 March 2019

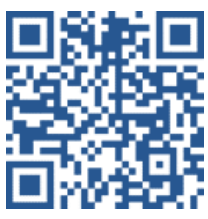
Cite this article-

Ahmad MP, Perween T, Singh S, Sinha R, Hussain A, Wahab S, Jha AK. Hepatoprotective activity of Asparagus racemosus root extract on lipopolysaccharide induced oxidative stress in rats. Universal Journal of Pharmaceutical Research 2019; 4(1): 7-11.

DOI: https://doi.org/10.22270/ujpr.v4i1.232

Address for Correspondence

Dr. Md. Parwez Ahmad, Associate Professor, Department of Pharmacology, National Medical College Teaching Hospital, Birgunj, Nepal. E-mail: parwezmedicine@gmail.com

\section{INTRODUCTION}

Lipopolysaccharide (LPS), gram-negative bacterial endotoxin induced hepatic failure has lead to high mortality. The severity of subsequent organ damage might depend on the difference between excess production of ROS and antioxidant defenses ${ }^{1-3}$. LPS binds to liver proteins, producing oxygen free radicals and proinflammatory cytokines ${ }^{4}$. Release of these toxic mediators is the contributing factor to most of LPS toxicity in the liver and in the systemic circulation ${ }^{5-6}$. LPS after binding to immune cells initiate a cascade of events that up-regulate expression of the inflammatory cytokines including TNF- $\alpha$, IL- 6 and IL- $1 \beta$. TNF- $\alpha$ and other cytokines stimulate the production of reactive oxygen species (ROS) and reactive nitrogen intermediates (RNIs) by activated macrophages causing liver damage ${ }^{7}$. The oxidative stress generated induces a rapid alteration in the antioxidant systems by depleting the cellular stores of endogenous antioxidants such as GSH, SOD and $\mathrm{CAT}^{8}$. The liver plays very important role in the defense against LPS induced toxicity. Asparagus racemosus has been scientifically investigated in experimental animals for their antiamnesic, diuretic, hypoglycaemic and antioxidant activity ${ }^{9}$. Earlier researchers have reported several phytoconstituents in plants viz. steroidal saponins, flavonoids, terpenoids, alkaloids, phenolics, carbohydrates, etc ${ }^{10}$.

The aim of the present study was to assess the liver damage in LPS administered rats and the hepatoprotective effect of root of A. racemosus. 


\section{MATERIALS AND METHODS}

Plant material and extract MEAR preparation

Root of A. racemosus Willd. was collected from Hamdard dawakhana, Lucknow in

2011. The plant material was identified and authenticated by a taxonomist of National Botanical Research Institute (NBRI) Lucknow and the voucher specimen number NBRI-SOP-202 was deposited in the departmental herbarium. The plant $A$. racemosus was air-dried and pulverized. The powdered material (500 gm) was packed in muslin cloth and subjected to soxhlet extractor with methanol for continuous hot extraction for $72 \mathrm{hrs}$ separately. There after methanolic extract of plant was filtered through Whatman paper no. 42 and the resultant filtrates was concentrated under reduced pressure and finally vacuum dried ${ }^{11}$. The yield of the methanolic extract was $10.4 \%$.

\section{Animals}

Adult male Sprague Dawley (SD) rats weighing 150$180 \mathrm{~g}$ were used in this study. They were kept in polyacrylic cages in group of 7 and maintained under standard housing condition (room temperature $25 \pm 1{ }^{\circ} \mathrm{C}$ and humidity (60-65\%) with $12 \mathrm{~h}$ light and dark cycle. The food and water were available ad libitum. The animals were procured from the Division of Laboratory Animal, Central Drug Research Institute, Lucknow, India. Experiments were performed as per internationally ethical standards, after obtaining clearance from animal ethics committee of the Integral University under Committee for the Purpose of Control and Supervision of Experiments on Animals, CPCSEA No-IU/Pharm/Ph.D/CPCSEA/12/03. Each group (control as well as treated) consists of 6 rats.

Drugs and Chemicals

Thiobarbituric acid (TBA), 2,6,-di-tert-butyl-4hydroxy-toluene (BHT), trichloroacetic acid (TCA), Hydrogen peroxide $\left(\mathrm{H}_{2} \mathrm{O}_{2}\right)$, EDTA, Tris buffer, Potassium dihydrogen orthophosphate, Disodium hydrogen ortho phosphate were obtained from $\mathrm{CDH}$, Mumbai. NADPH; DTNB were obtained from $\mathrm{Hi}$ Media, Mumbai. Cytokine ELISA kits were obtained from e Bioscience and Cayman Chemical USA. Lipopolysaccharide Serotype E. coli 0111:B4 were obtained from Sigma Chemicals, USA. Quercetin was obtained from Total herb solution Mumbai, India.

\section{Toxicity studies}

An acute toxicity study was performed for $A$. racemosus according to the Organisation for Economic Co-operation and Development guidelines by acute toxic classic method ${ }^{10}$. Three female (Sprague dawley) SD rats were used for each step in this study. The animals were fasted for overnight with only water available, after which the extracts were administered intragastrically at different doses of 50 and $300 \mathrm{mg} / \mathrm{kg}$. Food and water was withheld for a further 1-2 $\mathrm{h}$ after drug administration. Rats were closely observed for the initial $4 \mathrm{~h}$ after administration, and then once daily for 14 days to observe mortality. If mortality occurred in two of the three animals at any dose, then this dose was assigned as a toxic dose. If mortality occurred in one animal then the same dose was repeated to confirm the toxic dose. If mortality did not occur, the procedure was repeated for further higher doses, i.e. $2000 \mathrm{mg} / \mathrm{kg}$.

\section{Treatments}

Animals were randomly divided into seven groups as follows:-

Group I (control group): 1\% Carboxy methyl cellulose (CMC) $5 \mathrm{ml} / \mathrm{kg}$ p.o. once a day then challenged with normal saline i.p. on $21^{\text {th }}$ day.

Group II (LPS group): CMC $5 \mathrm{ml} / \mathrm{kg}$ p.o. once a day and then challenged with LPS Serotype E. coli 0111:B4, (4 mg/kg i.p.) on $21^{\text {th }}$ day $^{12}$.

Group III: (standard group) Quercetin $100 \mathrm{mg} / \mathrm{kg}$ p.o. daily and then challenged with LPS ( $4 \mathrm{mg} / \mathrm{kg}$ i.p.) on $21^{\text {th }}$ day ${ }^{13}$.

Group IV and V (Drugs treated groups): $100 \mathrm{mg} / \mathrm{kg}$ and $200 \mathrm{mg} / \mathrm{kg}$ p.o. daily respectively and then challenged with LPS (4 mg/kg i.p.) on $21^{\text {th }}$ day.

Group VI: $200 \mathrm{mg} / \mathrm{kg}$ of test drug and $100 \mathrm{mg} / \mathrm{kg}$ standard drug p.o. daily then challenged with LPS ( $4 \mathrm{mg} / \mathrm{kg}$ i.p.) on $21^{\text {th }}$ day.

Group VII (Perse group): $200 \mathrm{mg} / \mathrm{kg}$. p.o. daily for $21^{\text {th }}$ day. After six hours of LPS or saline injection blood was collected from tail vein for liver function test and all the animals were sacrificed, liver was removed, stored and homogenates was used for biochemical estimation.

\section{Determination of liver MDA content}

Suspension medium $(1 \mathrm{ml})$ was taken from the $10 \%$ tissue homogenate. TCA $(0.5 \mathrm{ml}$ of $30 \%)$ was added to it, followed by TBA reagent $(0.5 \mathrm{ml}$ of $0.8 \%$.) The tubes were then covered with aluminium foil and kept in shaking water bath for 30 minutes at $80^{\circ} \mathrm{C}$. After half an hour tubes were taken out and kept in ice-cold water for further thirty minutes and ccentrifuged at $3000 \mathrm{rpm}$ for 15 minutes ${ }^{15}$.

The absorbance of the supernatant was read at $540 \mathrm{~nm}$ at room temperature against appropriate blank.

\section{Determination of liver glutathione}

Liver tissue (300 $\mathrm{mg}$ ) was homogenized in EDTA (5 -8 $\mathrm{ml}$ of $0.02 \mathrm{M})$ and then cold distilled water $(4 \mathrm{ml})$ was added to it. After mixing it well, TCA ( $1 \mathrm{ml}$ of $50 \%$ ) was added and shaken intermittently for 10 minutes using a vortex mixer. After 10 minutes the contents were centrifuged at $6000 \mathrm{rpm}$ for 15 minutes. Following centrifugation, supernatant $(2 \mathrm{ml})$ was mixed with Tris buffer $(4 \mathrm{ml}$ of $0.4 \mathrm{M})$. The whole solution was mixed well and DTNB $(0.1 \mathrm{ml}$ of $0.01 \mathrm{M})$ was added to it. The absorbance was read within $5 \mathrm{~min}$ of the addition of DTNB at $412 \mathrm{~nm}$ against a reagent ${ }^{16}$. Determination of liver catalase

Liver tissue was homogenized in $50 \mathrm{mM} / \mathrm{L}$ potassium phosphate buffer with a ratio of $1: 10 \mathrm{w} / \mathrm{v}$. The homogenate was centrifuged at $10,000 \mathrm{rpm}$ at $4^{\circ} \mathrm{C}$ in a cooling centrifuge for 20 minutes. Catalase activity was measured in supernatant obtained after centrifugation. Supernatant $(50 \mu \mathrm{l})$ was added to cuvette containing $2.95 \mathrm{ml}$ of $19 \mathrm{mM} / \mathrm{L}$ solution of $\mathrm{H}_{2} \mathrm{O}_{2}$ prepared in potassium phosphate buffer. The change in absorbance was monitored at $240 \mathrm{~nm}$ wavelength at 1 minute interval for 3 minutes. Presence of catalase decomposes $\mathrm{H}_{2} \mathrm{O}_{2}$ leading to decrease in absorbance $^{17}$.

\section{Determination of Superoxide dismutase}

The supernatant was assayed for SOD activity by inhibiting pyrogallol autoxidation. Cytosolic 
supernatant $(100 \mu \mathrm{l})$ was added to Tris $\mathrm{HCl}$ buffer $(\mathrm{pH}$ 8.5). The final volume of $3 \mathrm{ml}$ was adjusted with the same buffer. Pyrogallol $(25 \mu \mathrm{l})$ of was added and changes in absorbance at $420 \mathrm{~nm}$ were recorded at 1 minute interval for 3 minutes. The increase in absorbance at $420 \mathrm{~nm}$ after the addition of pyrogallol was inhibited by the presence of $\mathrm{SOD}^{18}$.

Table 1: Effect of lipopolysaccharide, Quercetin and A. racemosus extract alone and in combination on oxidative stress markers in liver.

\begin{tabular}{|c|c|c|c|c|c|}
\hline Group & $\begin{array}{c}\text { Drug } \\
\text { treatment }\end{array}$ & $\begin{array}{c}\text { TBARS(nmols } \\
\text { MDA/mg } \\
\text { protein) }\end{array}$ & $\begin{array}{c}\mathrm{GSH}(\mu \mathrm{g} / \mathrm{mg} \\
\text { protein) }\end{array}$ & $\begin{array}{c}\text { CAT } \\
\left(\text { nmolH }_{2} \mathbf{O}_{2} / \mathbf{m g}\right. \\
\text { protein) }\end{array}$ & $\begin{array}{c}\text { SOD } \\
\text { (Units/mg } \\
\text { protein) }\end{array}$ \\
\hline I & Control & $3.502 \pm 0.0596$ & $3.292 \pm 0.043$ & $19.625 \pm 0.939$ & $2.64 \pm 0.086$ \\
\hline II & LPS & $6.33 \pm 0.0743^{* * *}$ & $1.666 \pm 0.035^{* * *}$ & $9.912 \pm 0.919^{* * * *}$ & $1.424 \pm 0.067^{* * * *}$ \\
\hline III & QT & $3.974 \pm 0.0812^{\# \# \#}$ & $2.876 \pm 0.073^{\# \# \#}$ & $15.716 \pm 0.285^{\# \# \# ~}$ & $2.20 \pm 0.087^{\# \# \#}$ \\
\hline IV & $\mathrm{AR}_{1}$ & $5.614 \pm 0.1062^{\# \#}$ & $1.794 \pm 0.022^{\mathrm{ns}}$ & $12.200 \pm 0.504^{\mathrm{ns}}$ & $1.584 \pm 0.058^{\mathrm{ns}}$ \\
\hline V & $\mathrm{AR}_{2}$ & 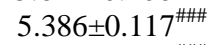 & $1.942 \pm 0.054^{\#}$ & $13.788 \pm 0.359^{\#}$ & $1.784 \pm 0.0508^{\#}$ \\
\hline VI & $\mathrm{AR}_{2}+\mathrm{QT}$ & $3.802 \pm 0.049^{\# \# \#}$ & $3.204 \pm 0.0423^{\# \# \#}$ & $17.70 \pm 0.475^{\# \# \#}$ & $2.324 \pm 0.0305^{\# \# \#}$ \\
\hline VII & $\mathrm{AR}_{2}$ perse & $3.598 \pm 0.113$ & $3.516 \pm 0.036$ & $19.292 \pm 1.066$ & $2.616 \pm 0.099$ \\
\hline
\end{tabular}

Results are expressed as mean \pm SEM. The results were analyzed by Analysis of variance (ANOVA) followed by Tukey-Kramer multiple comparison test. $\mathrm{n}=6,{ }^{\#}=p<0.05,{ }^{\# \#}=p<.01,{ }^{\# \#}=p<0.001, * * *=p<0.001,{ }^{\#}$ Vs. Group II, ${ }^{*}$ Vs. Group I

\section{Markers of liver function}

The activity of biochemical parameters such as AST and ALT were estimated by Reitman and Frankel method $^{19}$, ALP and TB were estimated by King and Dangerfield method ${ }^{20,21}$ ALB and TC level were estimated by the methods of Webster and Zlatkis, respectively $^{22,23}$.

\section{Determination of Nitric oxide (NO): Griess Reaction}

After the experiment, animals were sacrificed and the tissues were washed with PBS ( $\mathrm{pH} \mathrm{7.4)} \mathrm{and} \mathrm{placed} \mathrm{on}$ ice as described earlier. Sample $(50 \mu \mathrm{l})$ was added with Griess reagent $(100 \mu \mathrm{l})$ and reaction mixture was incubated for about 5-10 minutes at room temperature. The optical density was measured at $540 \mathrm{~nm}$ in microplate reader according to the reagent manufacturer's protocol. Calculations were done after generating a standard curve from sodium nitrite in the same buffer as used for preparation of homogenate ${ }^{24}$.

Enzyme-linked immunosorbent assay

Cytokines were measured from tissue samples using commercially available ELISAs for rat TNF- $\alpha$, IL- $1 \beta$ and IL-6. The ELISAs were operated according to the manufacturer's instructions. The intensity of the color measured is in proportion to the amount of rat cytokine bound in the initial steps. The sample values were then read off from the standard curve ${ }^{25}$.

\section{Statistical Analysis}

All results are expressed as mean \pm SEM. Groups of data was compared with analysis of variance (ANOVA) followed by Tukey-kramer multiple comparison test. $p<0.05$ was considered statstically significant.

\section{RESULTS AND DISCUSSION \\ Acute toxicity}

The extract from roots of $A$. racemosus administered orally to rats up to dose of $2000 \mathrm{mg} / \mathrm{kg}$ showed no toxicity and animal death during the evaluated period thus suggesting low toxicity of the extract. One-tenth and one-twenty of the maximum tolerated dose of the extract tested $(2000 \mathrm{mg} / \mathrm{kg})$ for acute toxicity did not indicate mortality and were selected for evaluation of the effect of $A$. racemosus i.e. 100 and $200 \mathrm{mg} / \mathrm{kg}$.

Oxidative stress markers

The level of GSH, SOD and CAT activity decreased and the level of lipid peroxidation (TBARS) in LPS only treated group increased. MEAR $(100 \mathrm{mg} / \mathrm{kg}$ and $200 \mathrm{mg} / \mathrm{kg}$ p.o.) supplementation was given for 21 days daily and on $21^{\text {st }}$ day single dose of LPS (4 $\mathrm{mg} / \mathrm{kg}$ i.p) was injected which restored depleted level of antioxidant enzyme i.e. GSH, SOD and CAT in the meanwhile decreased the level of TBARS (Table 1).

Table 2: Effect of lipopolysaccharide, Quercetin and A. racemosus extract alone and in combination on liver injury markers.

\begin{tabular}{|c|c|c|c|c|c|c|}
\hline $\begin{array}{l}\text { Drug } \\
\text { treatment }\end{array}$ & $\begin{array}{c}\text { SGOT } \\
\text { U/I }\end{array}$ & $\begin{array}{c}\text { SGPT } \\
\text { U/l }\end{array}$ & $\underset{U / \mathbf{I}}{\mathbf{A L K P}}$ & $\begin{array}{c}\text { TB } \\
\mathrm{mg} / \mathrm{dl}\end{array}$ & $\begin{array}{c}\text { ALB } \\
\text { g/dl }\end{array}$ & $\begin{array}{l}\text { CHL } \\
\mathrm{mg} / \mathrm{dl}\end{array}$ \\
\hline Control & $138.6 \pm 8.599$ & $113.24 \pm 7.314$ & $317.4 \pm 10.773$ & $0.924 \pm 0.058$ & $3.542 \pm 0.0737$ & $83.69 \pm 4.344$ \\
\hline LPS & $269.6 \pm 12.902^{* * * *}$ & $196.2 \pm 8.009^{* * *}$ & $397.6 \pm 8.447^{* * * *}$ & $1.504 \pm 0.048^{\text {**** }}$ & $1.736 \pm 0.030^{* * * *}$ & $21.908 \pm 4.432^{\text {**** }}$ \\
\hline QT & $172.4 \pm 8.078^{\# \# \#}$ & $128.8 \pm 7.940^{\#}$ & $322.6 \pm 12.428^{\# \# \#}$ & $1.142 \pm 0.0731^{\# \# \#}$ & $2.774 \pm 0.052^{\# \# \#}$ & $75.626 \pm 3.018^{\# \# \#}$ \\
\hline $\mathrm{AR}_{1}$ & $256.3 \pm 9.257^{\mathrm{ns}}$ & $179.4 \pm 6.337^{\mathrm{ns}}$ & $388.6 \pm 4.79^{\mathrm{ns}}$ & $1.292 \pm 0.033^{\mathrm{ns}}$ & $1.85 \pm 0.0761^{\mathrm{ns}}$ & $34.126 \pm 4.194^{\mathrm{ns}}$ \\
\hline $\mathrm{AR}_{2}$ & $209.2 \pm 10.012^{\# \#}$ & $163.2 \pm 5.113^{\#}$ & $331.2 \pm 8.691^{\# \# \# ~}$ & $1.2 \pm 0.024^{\# \#}$ & $2.066 \pm 0.049^{\# \#}$ & $42.86 \pm 6.344^{\#}$ \\
\hline $\mathrm{AR}_{2}+\mathrm{QT}$ & 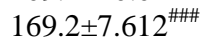 & $124.8 \pm 7.453^{\# \# \#}$ & $320.2 \pm 8.628^{\# \# \# ~}$ & $1.046 \pm 0.0710^{\# \# \# ~}$ & 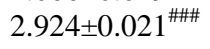 & $77.482 \pm 3.292^{\# \# \# ~}$ \\
\hline
\end{tabular}


Table 3: Effect of lipopolysaccharide, Quercetin and A. racemosus extract alone and in combination on cytokines and nitric oxide level.

\begin{tabular}{|c|c|c|c|c|c|}
\hline Group & $\begin{array}{c}\text { Drug } \\
\text { treatment }\end{array}$ & 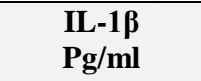 & $\begin{array}{c}\text { IL-6 } \\
\text { Pg/ml }\end{array}$ & $\begin{array}{l}\text { TNF-a } \\
\text { Pg/ml }\end{array}$ & $\begin{array}{c}\text { NO ( } \mu \text { mol nitrite/mg } \\
\text { of wet tissue) }\end{array}$ \\
\hline $\mathrm{I}$ & Control & $37.4 \pm 2.542$ & $136.4 \pm 4.377$ & $32.6 \pm 1.364$ & $3.24 \pm 0.108$ \\
\hline II & LPS & $73.6 \pm 5.115 * * *$ & $196.4 \pm 6.964 * * *$ & $51.6 \pm 3.027 * * *$ & $7.446 \pm 0.198 * * *$ \\
\hline III & QT & $52.8 \pm 3.555^{\# \#}$ & $149.31 \pm 6.189^{\# \# \#}$ & $37.12 \pm 2.345^{\# \#}$ & $5.488 \pm 0.140^{\# \# \#}$ \\
\hline IV & $\mathrm{AR}_{1}$ & $69.6 \pm 3.140^{\mathrm{ns}}$ & $168.21 \pm 5.391^{\#}$ & $45.4 \pm 4.707^{\mathrm{ns}}$ & $6.718 \pm 0.093^{\#}$ \\
\hline $\mathrm{V}$ & $\mathrm{AR}_{2}$ & $56.8 \pm 2.289^{\# \# \#}$ & $163.6 \pm 6.787^{\# \# \#}$ & $38.34 \pm 1.732^{\#}$ & $6.632 \pm 0.087^{\# \#}$ \\
\hline VI & $\mathrm{AR}_{2}+\mathrm{QT}$ & $50.8 \pm 2.672^{\# \# \#}$ & $140.4 \pm 5.636^{\# \# \#}$ & $36.6 \pm 3.763^{\# \#}$ & $4.854 \pm 0.145^{\# \# \#}$ \\
\hline VII & $\mathrm{AR}_{2}$ perse & $37 \pm 2.074$ & $137.81 \pm 5.187$ & $37.2 \pm 0.734$ & $3.106 \pm 0.174$ \\
\hline
\end{tabular}

\section{Liver function tests}

Liver function markers AST, ALT, ALP, TC, ALB and TB were assessed. Administration of LPS (4mg/kg, i.p, once) resulted in marked increase in serum AST, ALT, ALP and TB where as decrease in TC and ALB compared to corresponding control group (Table 2). MEAR supplementation (21 day) along with LPS (4 $\mathrm{mg} / \mathrm{kg}$ i.p on $21^{\text {th }}$ day) resulted in significant reduction in AST, ALT, ALP and TB whereas the level of TC and ALB increased compared with only LPS-treated group (Table 2).

\section{Nitric oxide}

In the rats pretreated with $A$. racemosus, the levels of NO significantly reduced compared to disease control (Table 3). Dose of $200 \mathrm{mg} / \mathrm{kg}$ was more effective than that of $100 \mathrm{mg} / \mathrm{kg}$.

\section{Cytokine Activity}

In the rats pretreated with $A$. racemosus, the levels of cytokines significantly reduced $(p<.001)$ as compared to disease control (Table 3). There was dose dependent recovery on the LPS induced elevation of the cytokines level in rats.

In the present study, administration of LPS to rats resulted in development of oxidative stress which led to damage in liver tissue in rats. This effect was indicated by an increase in the concentration of lipid peroxidation (TBARS), cytokines, nitric oxide and decrease in the concentration of the GSH, SOD and CAT (catalase). MEAR supplementation (21 day) along with LPS ( $4 \mathrm{mg} / \mathrm{kg}$ i.p on $21^{\text {th }}$ day) resulted in reduction in AST, ALT, ALP and TB whereas the level of TC and ALB increased compared with only LPS-treated group. LPS causes oxidative stress by intensification of proinflammatory cytokines production and by inducing the generation of ROS by different mechanisms ${ }^{26}$. Lipid peroxidation causes tissues injury by inactivation of membrane enzymes and receptors, depolymerization of polysaccharides as well as protein cross-linking and fragmentation ${ }^{27}$. Liver tissues are rich in polyunsaturated fatty acids and are known for its high oxygen uptake. Therefore, it is more susceptible to oxidative stress than other tissues ${ }^{28}$.

In current study $A$. racemosus root (MAER) significantly decreased liver cytokines level after $6 \mathrm{hr}$ of LPS administration as compared to rats treated with disease control. Root of $A$. racemosus supplementation increased the levels of GSH, SOD, CAT and decreased the level of TBARS, cytokines and nitric oxide significantly in the LPS-challenged animals. In a study done by Palanisamy and Manian showed that $A$. racemosus extract has hepatopotective activity by inhibiting production of free radical via inhibition of hepatic CYP2E1, increasing removal of free radical by induction of antioxidant enzyme and improving nonenzymatic thiol antioxidant $\mathrm{GSH}^{28}$.

Thus A. racemosus acts as a free radical scavenger ${ }^{29}$. In addition to its direct cytotoxic effects, it is able to induce chemokines macrophage chemotactic protein-1 and vascular cell adhesion molecule-1, which is the key to hyper inflammation and consequent liver damage ${ }^{30}$. A. racemosus is a medicinal plant with well-known antioxidant property. Scientific evaluation of this claim using experimental model of LPS induced oxidative stress in rats was ascertained in this study.

\section{CONCLUSION}

Oral administration of methanolic extract of $A$. racemosus root (MEAR) protected rats from LPS induced liver injury. The protection may be due to the reduction of oxidative stress which occurs by alteration in levels of antioxidant enzymes in rats. These observations suggest that MEAR may be clinically viable protection against variety of conditions where cellular damage is a consequence of oxidative stress. In conclusion, the present study provides experimental evidence for MEAR as a hepato-protective agent.

\section{AUTHOR'S CONTRIBUTION}

All authors have worked equally for this work.

\section{ACKNOWLEDGEMENTS}

We are grateful to Vice Chancellor Prof. S. W. Akhtar, Integral University, Lucknow, India for provide Lab. facilities for this research work.

\section{CONFLICT OF INTEREST}

No conflict of interest associated with this work.

\section{REFERENCES}

1. Kheir-Eldin AA. Motawi TK, Gad MZ, Abd-ElGawad HM. Protective effect of vitamin E, $\beta$-carotene and $\mathrm{N}$ acetylcysteine from the liver oxidative stress induced in rats by lipopolysaccharide. Int J Biochem Cell Biol 2001; 33: 475-482. https://doi.org/10.1016/S1357-2725(01)00032-2

2. Hines IN, Wheeler MD. Recent advances in alcoholic liver disease III. Role of the innate immune response in alcoholic hepatitis. Am J Physiol Gastrointestol Liver Physiol 2004; 287: G310-G14. https://doi.org/10.1152/ajpgi.00094.2004 
3. Tanguy S, Leiris $\mathrm{J}$ De, Besse S, Boucher F. Ageing exacerbates the cardiotoxicity of hydrogen peroxide through the Fenton reaction in rats. Mechan Ageing Dev 2004; 124: 229-35. https://doi.org/10.1016/S0047-6374(02)00185-9

4. Luster MI, Germolec DR, Yoshida T. Endotoxin-induced cytokine gene expression and excretion in the liver. Hepatology 1994:19:480-88.PMID: 8294104

5. Hartung T, Wendel A. Endotoxin-inducible cytotoxicity in liver cell cultures. J Biochemical Pharmacol 1991; 42: 112935. https://doi.org/10.1016/0006-2952(91)90298-J

6. Wang $\mathrm{H}$, Wei W, Zhang SY. Melatonin-selenium nanoparticles inhibit oxidative stress and protect against hepatic injury induced by Bacillus CalmetteGuerin/lipopolysaccharide in mice. J Pineal Res 2005; 39: 156-63. https://doi.org/10.1111/j.1600-079x.2005.00231.x

7. Victor VM, Fuente MD. Changes in the superoxide production and other macrophage functions could be related to the mortality of mice with endotoxin- induced oxidative stress. Physiol Res 2003; 52: 101-10.

8. Richard C, Lemonnier F, Thibault M. Vitamin E deficiency and lipoperoxidation during adult respiratory distress syndrome. Crit Care Med 1990; 18:4-9. https://doi.org/10.1136/thx.47.8.651

9. Lalana K, Wasu W, Penchom P, Kornkanok I, Neti W, Narong S. Antioxidant activity and antiapoptotic effect of Asparagus racemosus root extracts in human lung epithelial H460 cells. Exp Ther Med 2011; 2:143-148. https://doi.org/10.3892/etm.2010.172

10. Negi JS, Singh P, Joshi GP, Rawat M.S, Bisht VK. Chemical constituents of Asparagus. Pharmacogn Rev 2010 4(8): 215-220. https://doi.org/10.4103/0973-7847.70921

11. Gupta A. modern extraction methods for preparation of bioactive plant extracts. Int J App Nat Sci 2012; 1: 8-26.

12. The Organisation for economic cooperation and development. OECD guidelines for the testing of chemicals test no. 423. Acute oral toxicity-acute toxic class method, 2001

13. Ahmad MP, Hussain A, Siddiqui HH, Wahab S, Adak M. Effect of methanolic extract of Asparagus racemosus Willd. on lipopolysaccharide induced-oxidative stress in rats. Pak $\mathbf{J}$ Pharm Sci 2015; 28(2):509-13. PMID: 25730806

14. Ji-Hye K, Min-Jung K, Ha-Neul C. Quercetin attenuates fasting and postprandial hyperglycemia in animal models of diabetes mellitus. Nutr Res Pract 2011; 5: 107-1 https://doi.org/10.4162/nrp.2011.5.2.107

15. Ohkawa H, Ohishi N, Yagi K. Assay for lipid peroxides in animal tissues by thiobarbituric acid reaction. Analytical Biochem 1979; 95: 359-364.

https://doi.org/10.1016/0003-2697(79)90738-3

16. Sedlak J, Lindsay R.H. Estimation of total, protein bound, and nonprotein sulfhydryl groups in tissue with Ellman's reagent. Analytical Biochem 1968; 25: 192-205. https://doi.org/10.1016/0003-2697(68)90092-4

17. Clairbone A. Assay of Catalase. In: Greenwald RA, ed. Hand book of method of oxygen free radical research; Boca Raton, Fla; CRC pres, 1985, 283-4.

18. Marklund S, Marklun G. Involvement of super oxide anion radical in the auto oxidation of pyrogallol and a convenient assay for super oxide dismutase. Eur J Biochem 1974; 47: 469-474.https://doi.org/10.1111/j.1432-1033.1974.tb03714.x

19. Reitman S, Frankel SA colorimetric method for the determination of serum glutamate oxaloacetate transaminase. Amer J Clinic Pathol 1957:28: 53-56. https://doi.org/10.1093/ajcp/28.1.56

20. King J. The hydrolases-acid and alkaline phosphatases In: Practical Clinical Enzymology, London: Nostrand Company Limite, 191-208, 1965. https://doi.org/10.1155/2014/478973

21. Dangerfield WG, Finlayson R. Estimation of bilirubin in serum. J Clinic Pathol 1953; 6: 173.

22. Webster D. Interaction of bromocresol green with isolated serum globulin fractions. Clinica Chimica Acta 1974; 53: 109-115. https://doi.org/10.1016/0009-8981(74)90358-1

23. Zlatkis A, Zak B, Boyle A.J. A new method for the direct determination of serum cholesterol. J Lab Clin Med 1953; 41; 486-92.

24. Xie QW, Cho HJ, Calaycay J. Cloning and characterization of inducible nitric oxide synthase from mouse macrophages. Science 1992; 256: 225-8. https://doi.org/10.1126/science.1373522

25. Zhao L, Chen YH, Wang HJ. Reactive oxygen species contribute to lipopolysaccharide-induced tetragenesis in mice. Toxicological Sci 2008; 103:149-157. https://doi.org/10.1093/toxsci/kfn027

26. Jaworek J, Konturek S.J, Macko M. Endotoxemia in newborn rats attenuates acute pancreatitis at adult age. J Physiol Pharmacol 2007; 58: 131-147.

27. Luqman S, Rizvi SJ. Protection of lipid peroxidation and carbonyl formation in proteins by capsaicin in human erythrocytes subjected to oxidative stress. Phytother Res 2006; 20: 303-6. https://doi.org/10.1002/ptr.1861

28. Palanisamy N, Manian S. Protective effects of Asparagus racemosus on oxidative damage in isoniazid-induced hepatotoxic rats: an in vivo study. Toxicol Indus Health 2012; 28:238-44.https://doi.org/10.1177/0748233711410911

29. Hussain A, Ahmad M.P, Wahab S. A review on pharmacological and phytochemical profile of Asparagus racemosus willd. Pharmacol Online 2011; 3:1353-64.

30. Mark DT, Belinda N, Tara H, Daniel JP. Cytokines and chemokines: At the crossroads of cell signalling and inflammatory disease. Biochim Biophys Acta Mol Cell Res 2014; 1843: 2563-2582.

https://doi.org/10.1016/j.bbamcr.2014.05.014 